\title{
Foreword
}

\section{ARNOLD KRUPAT}

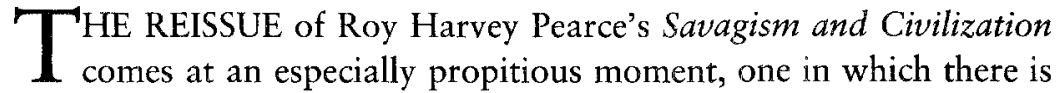
a renewed interest in cultural criticism attentive to discursive and ideological issues. Indeed, it is probably not too much to say that Pearce's book has played some real part in keeping the possibility of such criticism alive in America.

For when Savagism first appeared (in 1953, as The Savages of America: A Study of the Indian and the Idea of Civilization), there was very little literary interest in broad, historical studies of ideology and discourse. By discursive studies, I mean inquiries which, recognizing that all speech and writing are social as well as individual, inquire into how meanings are socially produced in any specific historical period. Ideological studies-I take, here, Terry Eagleton's recent statement as a useful working definition-are those that consider "the ways in which what we say and believe connects with the power-structure and power-relations of the society we live in." 'Such studies, as I have said, were hardly prominent in American criticism of the 1950s, a time when the dominant mode of study was that of the New Criticism which insisted upon an "intrinsic," essentially formalist critique of literature, one that located literary meaning not in the social practices-speech and writing among them-of everyday life, but in the "tensions," ironies, and paradoxes of language within "the poem itself"-poetry, inevitably, far more than any other kind of text, most

'Terry Eagleton, Literary Theory: An Introduction (Minneapolis, 1983), p. 14. 
obviously seeming to enjoy a relatively autonomous existence. Literary study for the New Critics had very little to gain from "extrinsic" attention to history.

But it was not only Pearce's broad concern for the ideological contours of discourse in history which made his book very different from most other studies of American literature; indeed, his particular choice of subject matter must also have seemed rather strange as well. For, although the years between the two World Wars had seen a flurry of interest in the Indian-anthologies of Native poetry appearing for the first time and Indian subjects attracting the attention of such diverse luminaries as Mary Austin, D. H. Lawrence, William Carlos Williams, and Yvor Winters, among others-nonetheless, I can think only of Albert Keiser's 1933 study, The Indian in American Literature, as even vaguely approximating Pearce's concern with EuropeanAmerican thought about the Native American. The only study roughly parallel in method to Pearce's work, Henry Nash Smith's Virgin Land (1950), took no notice whatever of Indians, although it was just recently, in a posthumously published piece, that Smith himself acknowledged that his study "would be a much better book if it showed even a partial awareness of the materials that would be brought together in subsequent years by Roy Harvey Pearce." 2

Pearce's study emerged from his graduate work at Johns Hopkins and his training in the method of intellectual history associated with Arthur O. Lovejoy, professor of philosophy at Hopkins, and generally referred to as "the history of ideas." It was Lovejoy's belief that ideas, or idea complexes as he called them, could be separated out of texts and discourses and studied logically and analytically in historical context. This procedure, "the thinking through of the logical possibilities

${ }^{2}$ Henry Nash Smith, "Symbol and Idea in Virgin Land," in Sacvan Bercovitch and Myra Jehlen, eds., Ideology and Classic American Literature (Cambridge, 1986), p. 28. In fact, Pearce's "The Significances of the Captivity Narrative," had already appeared, in 1947, before the publication of Smith's book. In that essay, Pearce showed, among other things, how one of the two earliest indigenously developed genres of writing in America-the other was the Indian War narrative- had taken the idea of the Indian as central to American thought. 
latent in any statement of belief or in any idea," ${ }^{3}$ as Pearce would later describe it, led to "understanding." Lovejoy's own work, for the most part, was content to remain at this analytic level. Pearce, however, wished to go on to the level of synthesis, in which "Combinations of unit ideas ... were placed in their socio"cultural contexts and were shown as they shaped men's minds and opinions leading them to acts." ${ }^{4}$ This was, as Pearce understood it, the "mode of interpretation" (one may note here how Pearce, meditating upon Lovejoy, was evolving the distinctions E. D. Hirsch would fully expound between what Hirsch called meaning and significance).

Before going on to consider Savagism itself, I must stop here to attend to what the theoretically minded reader may find paradoxical or even self-contradictory in my account thus far. For I have attempted to place Pearce's book in a context of discursive and ideological studies, describing these in a manner consistent with an approach to cultural work that is concerned to note the relationships between the economic and institutional arrangements of a society and its cultural productions. But I have also described Pearce's book as emerging from Lovejoy's "history of ideas" approach, which-rightly or wrongly-as Donald R. Kelley has recently noted, was precisely rebuked for its alleged failure to achieve a "social history of ideas." I will take this matter up again briefly, below, in referring Pearce's work to that of Michel Foucault. Here, let me say only that Pearce's approach to the study of hegemonic ideas includes a powerful concern for their "socio-cultural context," in his own phrase, and also for their material effects, the very real consequences of people's "acts" as these may be influenced by their ideas. Pearce began his 1953 Foreword to The Savages of America with the statement that "This is a book about a belief"-but one that was "planned according to

${ }^{3}$ Roy Harvey Pearce, Gesta Humanorum: Studies in the Historicist Mode (Columbia, Mo., 1987), p. 9.

${ }^{4}$ Pearce, p. 10.

${ }^{5}$ Donald R. Kelley, "Horizons of Intellectual History," Journal of the History of Ideas 48 (January-March 1987), p. 164, my emphasis. 
[a] structure of thought and action." "Pearce expanded upon and, as I see it, emphasized his concern for social action in the 1966 Postscript to the Foreword of the paperback edition, writing that "the book is a study of one of those unattractive 'isms' which taught our forebears how to make up their minds and also how to act" ( $\mathrm{x}$, my emphasis). Pearce's interest in the relation of ideas to social action would develop further in his later work. It is not Pearce's concern to follow ideas forward and backward in time from one individual master text to another in an attempt to document some ostensible triumphal emergence of ideological plenitude. Rather, with Bakhtin, Gramsci, and Raymond Williams, Pearce recognizes that there is always a social play of discourses even at those moments when a single discourse appears to have asserted its dominance, and so he very carefully traces the contours of the establishment of what Foucault himself would call disciplinary norms. At the risk of getting ahead of myself, let me say here that Pearce's work needs to be considered as an important practical supplement to Foucault-although, to be sure, Foucault's attention to the place of institutional factors in the production of hegemonic discourses provides a supplement to Pearce's achievement.

Lovejoy was particularly interested in primitivist ideas and the idea of the primitive, publishing (with George Boas) Primitivism and Related Ideas in Antiquity (1933), the initial volume of a projected "Documentary History of Primitivism and Related Ideas." Pearce took up aspects of this study. Among his first publications were studies of the eighteenth-century Scottish primitivist philosophers (1945) and of "Primitivistic Ideas in the Faerie Queene" (1945). Eventually he came to specify the primitivist idea most central to his interests as that of savagism, an idea that had importantly shaped American thought from the seventeenth century until the middle of the nineteenth. It would be Pearce's task in Savagism to show the way in which "the history of American civilization would . . . be conceived of as three-

${ }^{6}$ This Foreword is reprinted in the 1967 (revised) paperback edition (Baltimore, 1967), the first to restore the title Pearce originally had intended for the study, Savagism and Civilization: A Study of the Indian and the American Mind. My quotation is from p. vii, to which I have added the emphasis. All further references are to this edition and will be documented in the text. 
dimensional, progressing from past to present, from east to west, from lower to higher" (49), and how that conception, for almost two hundred and fifty years, would establish itself in relation to very specific social definitions of the Indian.

To achieve that task, Pearce offered substantive study of a range not often equaled to this day-to the point, indeed, where appreciation of the book's concrete detail has tended to obscure its theoretical, or as Pearce might prefer to say, its methodological clarity. In the Foreword to the first publication of Savagism Pearce announced that he would work with what he called "Idea, Syrnbol, and Image" as terms "meant to categorize, however roughly, stages in the history of an idea as it becomes part of a system of thought and action." "By Idea," he wrote, "I mean a predication, explicit or implicit, which offers a solution of a major human problem. By Symbol I mean a vehicle for an Idea.... By Image I mean a vehicle for a symbol" (vi-vii). The idea was the notion of the savage and savagism; "the Symbol is the Indian; and the Images are those found in social, historical, and imaginative writing of the period" (vii). The period specifically was 1609 to 1851 , the first date marking the publication of Richard Johnson's Nova Britania, a description of the wild and savage men said to inhabit Virginia, the second Lewis Henry Morgan's League of the Iroquois, perhaps marking a certain culmination (if not entirely the termination) of comparativist thinking judging Native "savagery" in relation to the pinnacle of European-American "civilization." (1851 is also the publication date of Henry Schoolcraft's Historical and Statistical Information Respecting the History, Condition, and Prospects of the Indian Tribes of the United States, a text that brings to an acute focus an older version of savagism at just the moment when Morgan's work in effect proposes the supercession of that view-proposes, that is, a new version of savagism.)

In general, Pearce distinguished three variants of American thought about the Indian in the two and a half centuries covered by his study. In the first, in the years roughly from 1609 up through the revolutionary 1770 s, Pearce's reading reveals that Indians were considered the same as all other men, capable, that is, of seduction by Satan-we are, of course, in a theocentric period-but also of salvation. The Puritan aim, then, was to transform the Indian, to improve him as. 
land might be improved, lifting him from the wild state of nature to civilization and to God. By the mideighteenth century, however, Pearce notes a decided ideological shift: "The problem, then, became one of understanding the Indian, not as one to be civilized and to be lived with, but rather as one whose nature and whose way of life was an obstacle to civilized progress westward" (41). By this time, the Indian was seen more nearly as noble savage than as minion of Satan; yet there was the paradox that while civilization could only destroy the peculiarly Native virtues of the Indian, only the civilized could survive. Perhaps what I have taken as a third version of savagism, that which prevails from about the first quarter of the nineteenth century, might better be seen as only a development or expansion of the immediately preceding period's view, for now the Indian is seen as the "Zero of human society," not as an early stage of civilization (by this time the concept of natural law has replaced that of divine providence, or God's will) but as bound by noncivilization: and so the Indian must vanish, for noncivilization is not life.

In two extraordinary final chapters, "The Virtues of Nature: The Image in Drama and Poetry" and "Red Gifts and White: The Image in Fiction," Pearce, having explored a great many texts generally neglected as "subliterary," considers a range of properly "literary" texts (drama, fiction, poetry)-and here he includes both noncanonical as well as canonical authors. He takes up, first, the works of poets and playwrights, from Robert Rogers, Hugh Henry Brackenridge, and Phillip Freneau in the eighteenth century, to Joseph Croswell, James Nelson Barker, and Lydia Sigourney early in the nineteenth, to Henry Wadsworth Longfellow (whose Hiawatha, published in 1855, sold out its first printing of 4,000 copies on the initial day of its appearance and ended its first year in print with a total of 38,000 copies sold). Next, he surveys the novelists from Cooper through Melville, with important attention to William Gilmore Simms, James Kirke Paulding, Robert Montgomery Bird, and many others who have not even yet received full critical study. Pearce himself would go on to further considerations of the poets of the revolutionary war period in his The Continuity of American Poetry (1961; 1987), and of such matters as the image of the Indian-hater (in Melville and others) in his Historicism Once More (1969) and Gesta Humanorum (1987). 
Nonetheless, although it is almost thirty-five years since Savagism first appeared, I think we have not quite yet followed out all the possible lines of inquiry the book suggested.

Pearce's methodology and his subject matter were, as I have indicated, very far from what was then the mainstream of American criticism. How far outside the mainstream-or how far in advance of its time--Pearce's work actually was may be indicated by its initial reception. According to Pearce himself, the book was either ignored or else misunderstood, at least by literary people, and only some few anthropologists (themselves just on the verge of founding the American Indian Ethnohistoric Conference and publishing for the first time the journal Ethnohistory in 1954) recognized the nature of the book's achievement.

And so it seems appropriate to conclude by elaborating on the point with which I began, the degree to which Pearce's study of a hegemonic idea in American culture is not merely of historical interest itself but represents a significant intervention in the criticism of today. For it has enabled, as I see it, such works as Richard Drinnon's Facing West: The Metaphysics of Indian-Hating and Empire Building (1980) and Lee Mitchell's Images of a Vanishing America (1981). I see it also as having exerted a powerful influence on such books as Richard Slotkin's Regeneration through Violence (1973), Michael Paul Rogin's Fathers and Children (1975), and Frederick Turner's Beyond Geography (1980). Perhaps better known than any of these is a book that is not on an American subject, Edward Said's Orientalism, a text that has frequently been called the first, perhaps the only, American study in the Foucauldian mode. And yet, there are ways in which Orientalism might also be referred to the Pearcean mode. In fact, Said studied Pearce's book only in the summer of 1979 (personal communication), after his own text had been completed. I invoke Said here by way of returning briefly to the issue I raised earlier, the relation of Pearce's work to Foucault's, a subject I think well worth further study. Both, for example, are similarly committed to the examination of broad ideological patterns that are represented in the discourse of historical epochs. Differences between them, however, are considerable. Perhaps the foremost of these is Pearce's increasingly militant humanism that may be compared to Foucault's increasingly militant 
antihumanism. ${ }^{7}$ And, Foucault's conception of episteme-his term for hegemonic discourse or dominant ideology (in the early work)-is totalized, encompassing and determining all endeavors to speak (with, in the later work, some unexplained local exceptions), while Pearce's view of belief systems or ideologies is much nearer to Raymond Williams' sense, which I alluded to earlier when also invoking Gramsci and Bakhtin, of the way in which dominant ideologies for all their dominance cannot help but permit a certain play to what Williams terms residual and emerging values, or, as Pearce himself might put it, the way in which all cultures are both enabling and disabling at once, encouraging and forestalling a sense of individualism that can only reach its fullness--perhaps paradoxically, perhaps not-in community. Finally, there is the difference between Pearce's and Foucault's relation to the explanation of continuity and change: Pearce is attentive to shifts and modifications, although perhaps less than fully attentive-as Smith belatedly suggested ${ }^{8}$ - to the material bases of such alterations, while Foucault's conceptualization is rather uninterested in and so unable to account for change. Pearce's work, as I have noted, originally emerged from Arthur Lovejoy's history of ideas. Now, in The Archeology of Knowledge (1972, in English; French original, 1969), Foucault, attempting to define his own archeological method, found it useful to mount a specific attack on the history of ideas, distancing himself from its procedures. But it is not at all clear who Foucault takes as representing the history of ideas as he describes it, for he does not-this is unfortunately all too common in his workoffer the name of a single practitioner, nor is it likely, so gallocentric is his work, that he is thinking of Lovejoy, surely not of Pearce. Here might be something well worth pursuing.

Today, we may salute the appearance of the new Harper Anthology of American Literature (1985) for the reason that it gives us a major

${ }^{7}$ For an attempt to suggest possibilities for joining-if not fully reconciling-Pearce's humanism to some current antihumanist positions, see my "Criticism and the Canon; Pearce and the Indians: Cross Relations," Diacritics (to appear February 1988), which also offers something of an overview of Pearce's work as a whole.

${ }^{8}$ In a note to the essay cited above, p. 35. 
teaching anthology that finally includes some Native American materials (if not always the most interesting ones); we have the collection of essays edited by Sacvan Bercovitch called Reconstructing American Literary History (1986), to follow upon Paul Lauter's important initiative for the Feminist Press, Reconstructing American Literature (1983, with a revisionist anthology soon to follow); when Bercovitch and Myra Jehlen have collaborated on a collection called Ideology and Classic American Literature (1986); and the University of California Press has initiated a series in the New Historicism: Now, in the light of these salutary developments, a new edition of Roy Harvey Pearce's Savagism and Civilization is most welcome. A book that, as I said at the outset, has played a real part in making these developments possible, Savagism seems likely to make an ongoing contribution to the study of American thought and American literature-and as well ( 1 close by opening a related subject) to the study of Native American literature in an intellectual climate that can no longer be unaware of the existence and the nature of "savagist" modes of thought. 
This page intentionally left blank 